\title{
Trophic quality of waters in the Patos Lagoon estuary: a comparison between its margins and the port channel located in Rio Grande, RS, Brazil
}

\author{
Qualidade trófica das águas no estuário da Lagoa dos Patos (RS, Brasil): comparação \\ entre suas margens e o canal do porto localizado em Rio Grande, RS, Brasil
}

Rafela Neves Marreto ${ }^{1 *}$, Maria da Graça Zepka Baumgarten ${ }^{1}$ and Mônica Wallner-Kersanach ${ }^{1}$

${ }^{1}$ Instituto de Oceanografia, Universidade Federal do Rio Grande - FURG, Av. Itália, Carreiros, Km 8, CEP 96201-900, Rio Grande, RS, Brazil

*e-mail: rafaela_marreto@yahoo.com.br

Cite as: Marreto, R.N., Baumgarten, M.G.Z. and Wallner-Kersanach, M. Trophic quality of waters in the Patos Lagoon estuary: a comparison between its margins and the port channel located in Rio Grande, RS, Brazil. Acta Limnologica Brasiliensia, 2017, vol. 29, e11.

\begin{abstract}
Aim: This study aimed to evaluate the Trophic State Index (TSI) at the margin and in the channel of the Patos Lagoon estuary, considering different hydrological conditions. Methods: Surface and bottom water samples were collected in three sites in the channel (margin and center) and in two sites at the Saco da Mangueira in different hydrological conditions in 2011. Results: Waters at the Saco da Mangueira are very contaminated by phosphate and nitrogenous compounds. The TSI classifies these waters as being hypereutrophic, the consequence of both the release of effluents which were poorly treated and the low water flow in the inlet. Contamination was mild at the margins of the channel, where waters were classified as being eutrophic and mesotrophic. Trophic balance (mesotrophic waters - oligotrophic surface - bottom) was found in the center of the channel as a consequence of strong water flow and dilution of contaminants coming from the margins. Conclusions: Spatial variation in the TSI value enabled clear distinction to be observed between the areas at the margins and in the channel, because it reflected the punctual presence of anthropogenic input in the marginal waters, mainly in the Saco da Mangueira. Effluent treatment must be required in order to control severe trophic imbalance in the waters at the margins of the city. Variations of the proposed index are a useful tool to identify sources of phosphate compounds in other aquatic environments.
\end{abstract}

Keywords: effluents; organic contamination; phytonutrients; Trophic State Index.

Resumo: Objetivo: O objetivo deste estudo foi avaliar o Índice de Estado Trófico (IET) das margens e do canal da Lagoa dos Patos, considerando diferentes condiçóes hidrológicas. Métodos: amostras de águas da superfície e do fundo foram coletadas em 2011 em três locais no canal (margem e centro) e em dois locais do Saco da Mangueira em diferentes condiçôes hidrológicas. Resultados: As águas do Saco da Mangueira são muito contaminadas por fosfato e compostos nitrogenados. O TSI classifica estas águas como sendo hipertróficas, como consequência de ambos, a liberaçáo de efluentes que são pouco tratados e baixo fluxo de água na enseada. No eixo deste canal houve equilíbrio trófico (águas mesotróficas - superfície e oligotróficas - fundo), consequência da intensa circulação da água e diluição dos contaminantes oriundos das margens. Conclusóes: A variaçáo espacial nos valores do TSI indicou uma distinção clara entre as áreas nas margens e no canal, visto que refletem a presença pontual de aportes antropogênicos nas águas de margem, principalmente do Saco da Mangueira. 
O tratamento dos efluentes deve ser uma exigência para controlar os graves desequilíbrios tróficos das águas na margem da cidade. A mudança no cálculo do TSI indica ser uma ferramenta útil para identificar fontes de compostos fosfatados, podendo ser aplicado para qualquer ambiente aquático.

Palavras-chave: efluentes; contaminação orgânica; fitonutrientes; índice do estado trófico.

\section{Introduction}

Estuaries are ecosystems which have high productivity and decomposition of organic material. Their hydrodynamic complexes turn them into temporary storage sites of suspended material and elements - sometimes pollutant ones - associated with them (Hartmann \& Schettini, 1991). Retention of nutrients in the estuarine environment is the main contributing factor to the high productivity found in these environments. It enables intense proliferation of opportunistic microalgae in the form of blooms which may release toxins, thus, decreasing natural biodiversity and harming the quality of the water; as a result, trophic imbalance is generated (Rabalais et al., 2010).

The evaluation of trophic imbalance in the water is based on nutrient availability, associated with data on biomass or photosynthetic pigments (chlorophyll a), besides other parameters, such as dissolved oxygen. However, the complexity of the interaction among parameters involved in this process makes it a hard task. This aspect supports the relevance of the use of quantitative numerical indices for the determination of the trophic water quality, involving the integration of several parameters, which provide better spatial and temporal coverage. Generation of water classification using numerical trophic indices provides subsidies for the formulation of public management programs that aim at the preservation and good management of water resources (Baumgarten \& Paixão, 2013; O'Boyle et al., 2013).

Many trophic quality indices and trophic scales are available for lakes, estuaries and marine coastal areas in the literature. All indices were adapted, based on the input of nutrients in the aquatic ecosystem, depending on the characteristic and peculiarity of eutrophication (Gupta, 2014).

The term Trophic State Index (TSI) was originally defined by Carlson (1977), and could demonstrate the trophic status of the lakes. The author reported three different TSI values, the total phosphorus, chlorophyll- $a$, and transparency (Secchi disk). The TSI enables further eutrophication classification of the lake into oligotrophic, mesotrophic, and eutrophic ones. To better assess the water quality in lakes, Osgood (1982) suggested using differences in the indices. The Trophic State Index for lagoons has also been modified with the use of nitrite-nitrogen, chlorophyll-a, and Secchi disk depth for the estimation of the status of eutrophication (Gupta, 2014). Other approaches used the trophic index TRIX, based on Chl-a, oxygen saturation, total nitrogen, and phosphorus (Vollenweider et al., 1998), but it has more useful applications to saline coastal marine waters, rather than to brackish water lagoon (Gupta, 2014). The same limitation was observed for the integrated model for the Assessment of Estuarine Trophic Status (ASSETS) developed by Bricker et al. (2003). A recent and simplified index of the status of eutrophication was developed by using $\mathrm{pH}$ - and dissolved oxygen saturation for estuaries and coastal bays (O’Boyle et al., 2013). Some comparison between the TRIX and the ASSETS indicated that TRIX can be used as an indicator of trophic state whereas ASSETS showed good potential to assess eutrophication in coastal areas (Lai et al., 2014). However, some similarities between both, the index and the model, were evident in an estuarine area located on the southern coast in Pernambuco, Brazil (Alves et al., 2013). TRIX was also more efficient to indicate the trophic state of Guanabara Bay, Rio de Janeiro, Brazil (Santos, 2015), in comparison with the TSI developed by O'Boyle et al. (2013), since this bay has a high seawater exchange.

Considering the limitation of a more recent index for brackish water lagoons, the adaptation of TSI seems to be more suitable to be applied to these areas. A different approach of the TSI calculation to be applied to continental and estuarine waters in Brazil was observed by some previous studies. This index was modified by Toledo Junior et al. (1983) and then altered again by Mercante \& Tucci-Moura (1999). The calculation of this index takes into consideration variables, such as total phosphorus, the photosynthetic pigment chlorophyll $a$, transparency and total nitrogen, which are directly connected to processes that influence the trophic balance of the water. Afterwards, Lamparelli (2004) not only optimized this index, including turbidity for lotic and transparency for lentic waters ones, individually, dissolved phosphorus (ortophosphate) and total nitrogen, but also detailed the interpretation of the trophic quality of water in six trophic classes. 
Baumgarten \& Paixão (2013) have recently optimized the Lamparelli (2004) TSI for waters in the southern area of the Patos Lagoon estuary (southern Brazil), excluding transparency, due to the abundant suspended particulate material in the water. This recommendation had previously been made by CETESB (2007). Since the estuary has a significant contribution of nutrients, mainly phosphate in the water, this recent TSI has included this parameter, as well.

However, the trophic classification of Baumgarten \& Paixão (2013) neither took into account its temporal variation in that area nor the evaluation of marginal waters in the channel, where anthropogenic input and the development of opportunistic blooms are high (Baumgarten \& Niencheski, 2010). Since these environments have distinct water circulation and characteristics, which lead to differences in self-depuration capacity and anthropogenic input, they should be evaluated simultaneously in order to compare their trophic qualities.

Therefore, the objective of this study was to evaluate the trophic quality at the margin and in the channel of this estuary, considering different hydrological regimes in the estuary.

This study aimed to evaluate the Trophic State Index (TSI) at the margin and in the channel of the Patos Lagoon estuary, considering different hydrological conditions.

\section{Material and Methods}

\subsection{Location and characterization of the study area}

The Patos Lagoon estuary, in southern Brazil, has a narrow channel that restricts the tidal influence, which has a low range $(0.47 \mathrm{~m})$ (Möller et al., 2001). Geomorphological events in the late Pleistocene created the original estuarine conditions. However, erosion and deposition processes by Holocene morphodynamics were responsible for the evolution of the present Patos Lagoon estuary (Calliari et al. 2009). The Patos Lagoon $\left(10,360 \mathrm{~km}^{2}\right)$ can be classified as partially closed lagoon and defined as the world largest choked lagoon (Kjerfve, 1986). Water residence time depends more on weather conditions than on the tide. The predominant NE-SW wind regime is the principal forcing factor that controls water levels, circulation and salinity distribution. The NE wind forces the freshwater runoff and SW wind forces the seawater to penetrate into the lagoon (Garcia, 1997). Thus, freshwater has a long residence time in the winter (June-August) and the salt-water can reach up to $200 \mathrm{~km}$ in summer (January-March) (Niencheski et al., 1994).

Rio Grande, a city located in the estuary, has around 200,000 inhabitants and is bordered by inlets which differ from the channel areas in several aspects, such as low depth, intense artisanal fishing and more protected geographical conditions with low water circulation, mainly on its margins. The city has three port areas (Figure 1) and an

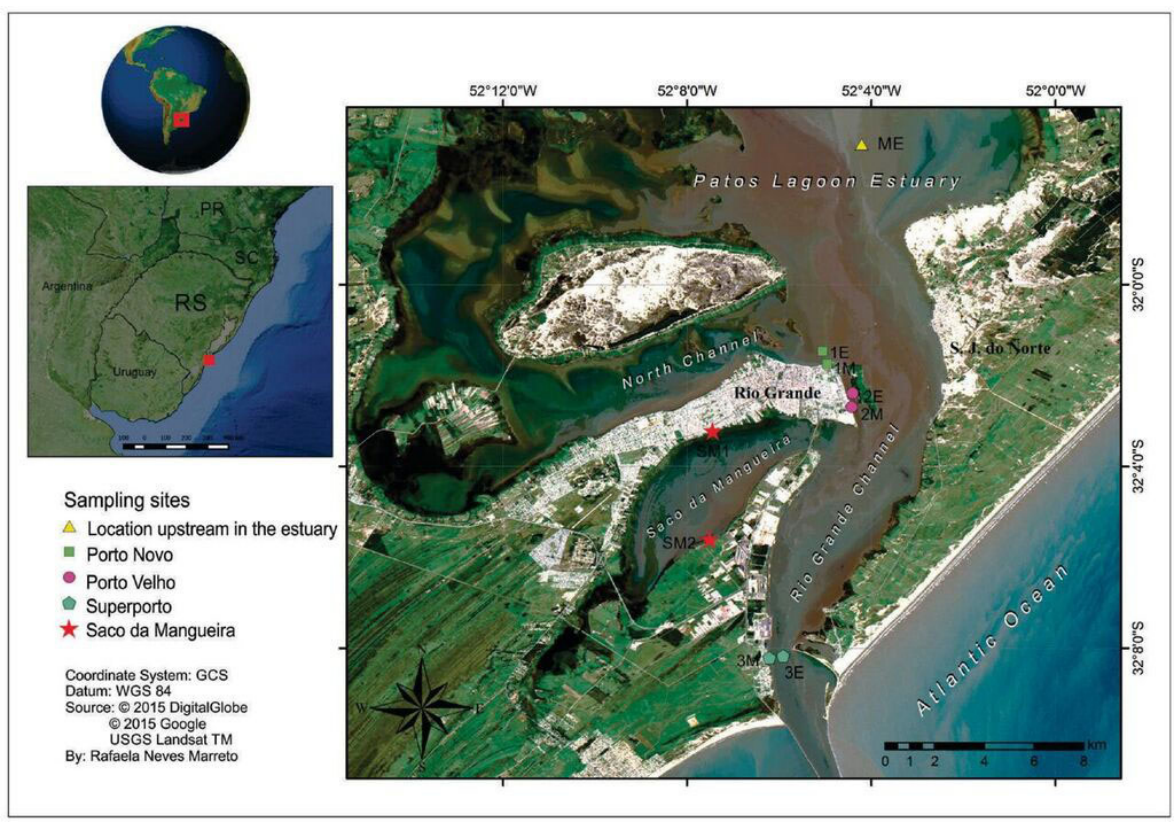

Figure 1. Sampling sites in the south of the Patos Lagoon estuary: Rio Grande Channel - margin (1M, 2M and 3M) and channel axis (1E, 2E and 3E); and Saco da Mangueira (SM1 and SM2). 
industrial park with fish industries, a refinery, a container terminal, shipyards, fertilizer and vegetable oil plants. They favor effluent discharge on the margins of the city and in the Rio Grande Channel, which has been heavily used for navigation and general port activities.

The shallow inlet the Saco da Mangueira (Figure 1), which is located in the south of Rio Grande, is semi-closed in the area where it flows into the Rio Grande Channel. According to Fernandes et al. (2007), water residence time at Saco da Mangueira is higher than the one in the channel waters. The dynamics of this inlet is directly related to the one of the Rio Grande Channel. Saco da Mangueira, together with many other areas in the estuary, is important to the development of commercial species. The industrial district in Rio Grande is located on one of its margins while urban occupation has been developed along the appositive margin. Saco da Mangueira officially belongs to the preservation area; therefore, they are considered Class B - brackish waters (FEPAM, 1995). Despite this fact, the inlet receives high amounts of poorly treated effluents. Previous studies, identified 22 sites where effluents were discharged; most were industrial and domestic ones (Almeida et al., 1993). A recent study of this environment identified 49 sites where anthropogenic effluents were discharged into this inlet; $49 \%$ had contamination levels of organic matter ranging from medium to very strong, mainly from food industries and fertilizer plants (Wallner-Kersanach et al., 2016).

The current sewage collection system in Rio Grande, which collects $32 \%$ of the effluents generated by the city, is inadequate to the size and development of the city. Although the city has expanded its sewage collection system, it has not spread over most of the city yet.

\subsection{Sampling and analysis}

Water samples were collected in the estuarine part of the Patos Lagoon at the end of the each seasons of the year (February, June, July and October 2011), during four cruises. Samplings were carried out in three sites located in the port area in Rio Grande (old port, new port and industrial port), at the margin and along the longitudinal axis of the estuary (Rio Grande Channel) (Figure 1). Two sampling sites were selected at the Saco de Mangueira as well. Simultaneous samplings were conducted at the margin and in the channel.

In every site, water column samples collected on the surface and at the bottom with the use of a Niskin bottle and aliquots were placed in pre-cleaned polyethylene bottles. Parameters under analysis were dissolved nutrients (phosphate and ammoniacal nitrogen mentioned as ammonium), total phosphorus and photosynthetic pigment (chlorophyll $a$ ) whereas the physico-chemical parameters were salinity, temperature, dissolved oxygen (mg. $\mathrm{L}^{-1}$ and $\%$ of saturation), Biochemical Oxygen Demand $\left(\mathrm{BOD}_{5}\right), \mathrm{pH}$ and suspended material (SM). Such parameters were chosen because they reflect the influence of anthropic activities on the environment. Data on channel waters were obtained by the "Environmental Monitoring from the Channel to the New Port Evolution Basin and of the Discharging Area of Dredged Matter", a partnership between the Universidade de Rio Grande (FURG) and the Superintendência do Porto de Rio Grande (SUPRG).

Water samples were kept in refrigerators before and during transportation to the laboratory. They were filtered in cellulose acetate filters with porosity of $0.45 \mu \mathrm{m}$ so that the suspended material and the phytonutrients (phosphate, ammonium) could be analyzed. In the case of the phytonutrients, $50 \mathrm{~mL}$ aliquots were frozen up to the analysis. The determination of the concentrations of suspended material in the samples was carried out by gravimetry. Analyses followed the methods described by Baumgarten et al. (2010).

Bottles with the water samples for the analysis of total phosphorus were immediately frozen. The determination of the concentrations (in mg. $\mathrm{L}^{-1}$ ) of this parameter was carried out by the analysis method described by APHA (1992).

In the case of the analysis of the pigment chlorophyll $a$, the sample was filtered by gravity in a glass fiber filter. The analysis of the pigment kept by the filter was carried out in agreement with the method described by Mackiney (1941) and concentrations were expressed in $\mu \mathrm{g} \cdot \mathrm{L}^{-1}$.

The concentration of dissolved oxygen and its Biochemical Oxygen Demand $\left(\mathrm{BOD}_{5}\right)$ were determined by the titration method; the $\mathrm{BOD}_{5}$ was calculated after samples had gone through a 5-day incubation period, according with Baumgarten et al. (2010). In samples collected in the channel, oxygen concentrations and the $\mathrm{BOD}_{5}$ were determined by a portable digital oximeter (Metler 0128 - Toledo). Concentrations were expressed in mg. $\mathrm{L}^{-1}$.

Temperature and salinity were determined by a thermosalinometer WTW cond. 315i during the water sampling. 


\subsection{Calculation of the Trophic State Index (TSI)}

The TSI values of all sampling sites were calculated by the equations optimized for the Patos Lagoon estuary by Baumgarten \& Paixão (2013). The optimization of this index defined that the equations should account for the results of phosphate, chlorophyll $a$ and total phosphorus, since all are chemical indicators of trophy in the environment. In the literature, the inclusion of phosphate in equations to calculate the TSI is not unanimous.

Therefore, in order to calculate the total TSI of the estuary, specific TSI values of the total phosphorus (TP), chlorophyll $a(\mathrm{Chl} a)$ and phosphate or reactive soluble phosphorus (RSP) were calculated by Equations 1, 2 and 3 described by Lamparelli (2004). They are also used by CETESB (2007) for total phosphorus and chlorophyll $a$ and by Toledo Junior et al. (1983) for phosphate.

Equations used for calculating the specific TSI values are:

$$
\begin{aligned}
& \text { TSI }(\text { Chla })=10 *\{6-[-0.7-0.6 *(\ln \text { Chla }) / \ln 2]\}-20 \\
& \text { TSI (TP) }=10 *\{6-[0.42-0.36 *(\ln \text { PT }) / \ln 2]\}-20(2) \\
& \text { TSI (RSP) }=10 *\{6-[\ln (21.67 / \text { RSP }) / \ln (2)]\}
\end{aligned}
$$

where: In Chla is the Napierian logarithm of the concentration of chlorophyll $a$ ( $\left.\mu \mathrm{g} . \mathrm{L}^{-1}\right)$;

$\ln \mathrm{TP}$ is the Napierian logarithm of the concentration of total phosphorus ( $\left.\mu \mathrm{g} . \mathrm{L}^{-1}\right)$;

RSP is the concentration of reactive soluble phosphorus or phosphate $\left(\mu \mathrm{g} \cdot \mathrm{L}^{-1}\right)$.

*means multiplication

In these calculations, the original units of phosphate $\left(\mu \mathrm{M} \mathrm{P}-\mathrm{PO}_{4}^{3-}\right)$ and total phosphorus (mg. $\left.\mathrm{L}^{-1}\right)$ were transformed into $\mu \mathrm{g} \cdot \mathrm{L}^{-1}$. Original results of chlorophyll $a$ had already been expressed in $\mu$ g. $L^{-1}$.

The calculations of specific TSI values in every site under analysis (every sample) led to the values of total TSI values which were obtained by the equation showed in Equation 4:

Total TSI $=$ TSI $($ Chla $)+$ TSI $(\mathrm{tP})+$ TSI $($ RSP $) / 3$

The association of total TSI values with different trophic state categories is shown in Table 1.

\subsection{Statistical treatment of data}

In order to evaluate the influence of every parameter on the variation of total TSI in the waters at the margins and in the channel, the Spearman's Linear Correlation Coefficients were calculated for non-parametric data with $95 \%$ confidence level. The sites and the four seasonal samplings were grouped. To carry out this calculation, data on ammonium in $\mu \mathrm{M}$ were transformed into $\mu \mathrm{g}$. $\mathrm{L}^{-1}$. The same was carried out with data on phosphate, total phosphorus and chlorophyll $a$ to be used in the equations. Thus, equivalence of units and magnitude among correlated data was generated so that the correlations could better show the real intercorrelation among variables.

Rainfall data of the study area were verified 30 days prior of the samplings and obtained by the Praticagem da Barra do Rio Grande (RGPILOTS, 2016).

\section{Results}

\subsection{Physico-chemical parameters and the Biochemical Oxygen Demand $\left(B O D_{5}\right)$}

Dissolved oxygen (DO) concentrations and its saturation in the waters of both sampled areas (margin and channel) are in agreement with Brazilian environmental legislation $\left(\mathrm{DO}>5 \mathrm{mg} \cdot \mathrm{L}^{-1}\right.$ FEPAM, 1995, DO >100\% - CONAMA, 2005, Class 2, brackish water), except the marginal water in the channel, close to the Porto Novo (2M site), where there were important subsaturations in winter, both on the surface and at the bottom (65.37\% and $71.83 \%$, respectively).

The values of the Biochemical Oxygen Demand $\left(\mathrm{BOD}_{5}\right)$ in the sites located in the channel, both on the surface and at the bottom $\left(<5 \mathrm{mg}\right.$. $\left.\mathrm{L}^{-1}\right)$, are in accordance with the environmental legislation. In marginal surface waters, there was increase in concentrations at the sites SM1 and SM2 in spring, and at the sites $1 \mathrm{M}$ in winter and $2 \mathrm{M}$ in fall. The highest $\mathrm{BOD}_{5}$ observed in these waters exceeded the maximum limit recommended by the legislation, i. e. $8 \mathrm{mg} . \mathrm{L}^{-1}$, the double of maximum value recorded in the channel $\left(4.06 \mathrm{mg} \cdot \mathrm{L}^{-1}\right)$.

Regarding the suspended material (SM), most concentrations of this parameter in the channel and at its margin ranged from 30 to $50 \mathrm{mg} . \mathrm{L}^{-1}$. There was considerable increase in the concentrations of this parameter at the surface of Saco da Mangueira, in spring and summer. The maximum value was found in spring, i. e. $260 \mathrm{mg} . \mathrm{L}^{-1}$ at $\mathrm{SM} 2$ site.

Table 1. Limits of the TSI and trophic classes (Lamparelli, 2004).

\begin{tabular}{cc}
\hline Trophic classes & Total TSI \\
\hline Ultraoligotrophic & $<47$ \\
Oligotrophic & $47<\mathrm{TSI}<52$ \\
Mesotrophic & $52<\mathrm{TSI}<59$ \\
Eutrophic & $59<\mathrm{TSI}<63$ \\
Supereutrophic & $63<\mathrm{TSI}<67$ \\
Hypereutrophic & $>67$ \\
\hline
\end{tabular}


Salinity in the sampling periods is in agreement with the seasonal pattern established by Möller et al. (2001): summer had the highest salinity (the maximum was 34.3), fall showed had mixoaline salinity, ranging from 9.6 to 16.8 , winter showed almost low salinity (between 0.3 and 3.2) and spring had strongly mixoaline waters. This parameter differentiated, with no pattern, the environment in the inlet and the channel: the salinity at Saco da Mangueira is lower than the one at the Rio Grande Channel in summer and spring. However, it is higher in the inlet than in the channel in fall and winter.

\subsection{Dissolved nutrients and total phosphorus}

Concentrations of phosphate and total phosphorus were higher in marginal water than in waters in the channel (Figure 2). Regarding phosphate, concentrations were even ten-fold the mean value observed in the channel. At the channel margin, it only occured in bottom waters in summer (0.33 mg.L $\mathrm{L}^{-1}$ ) whereas, at the Saco da Mangueira, concentrations were high at site SM1 in winter $\left(0.15 \mathrm{mg} . \mathrm{L}^{-1}\right)$ and at the SM2 site in summer, fall and winter $\left(0.13 ; 0.30 ; 0.17 \mathrm{mg} . \mathrm{L}^{-1}\right.$, respectively).

Concentrations of total phosphorus only showed enrichment in the waters from Saco da Mangueira, where they were about three-fold the ones found in the channel (maximum value was $0.3 \mathrm{mg} . \mathrm{L}^{-1}$ ) in fall, on the
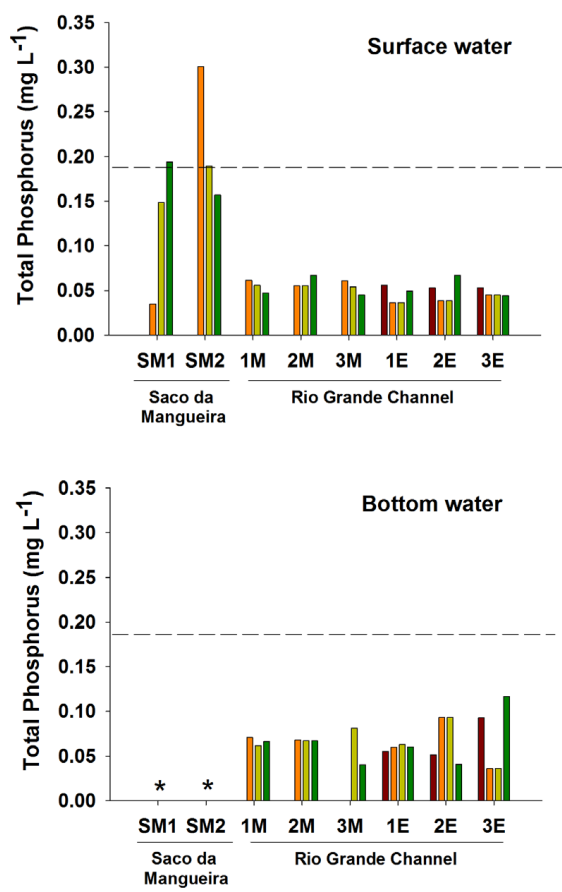

surface at site SM2. The second highest concentration (0.19 mg. $\left.\mathrm{L}^{-1}\right)$ was found at site SM1 in spring.

Concentrations of total phosphorus in the channel are in agreement with the environmental legislation (CONAMA, 2005); reference value for total phosphorus was $\left.0.186 \mathrm{mg} \cdot \mathrm{L}^{-1}\right)$. Concerning phosphate, this parameter has not been cited in the environmental legislation; its concentrations are compared to reference values which are considered normal in non-polluted estuaries (Aminot \& Chaussepied, 1983; reference value for phosphate is $\left.0.031 \mathrm{mg} \cdot \mathrm{L}^{-1}\right)$. Values obtained by this study are a little above this limit.

Regarding ammonium, concentrations of this phytonutrient in marginal surface waters were generally higher than the ones at the bottom (Figure 3). Emphasis should be given to site SM2 at the Saco da Mangueira in fall and spring (0.66 and $0.44 \mathrm{mg} . \mathrm{L}^{-1}$, respectively) and, to a lesser extent, to site SM1 in winter $\left(0.27 \mathrm{mg} \cdot \mathrm{L}^{-1}\right)$. At the margin of the channel, site $1 \mathrm{M}$ in spring (0.49 mg. $\left.\mathrm{L}^{-1}\right)$ should be highlighted.

Concerning magnitude of concentrations, values recorded in Saco da Mangueira (SM2) and at the channel margin close to Porto Velho (1M) were about two- or three fold the ones found in the channel, where the highest concentration was $0.15 \mathrm{mg} \cdot \mathrm{L}^{-1} \mathrm{~N}-\mathrm{NH}_{4}^{+}$(1M site).

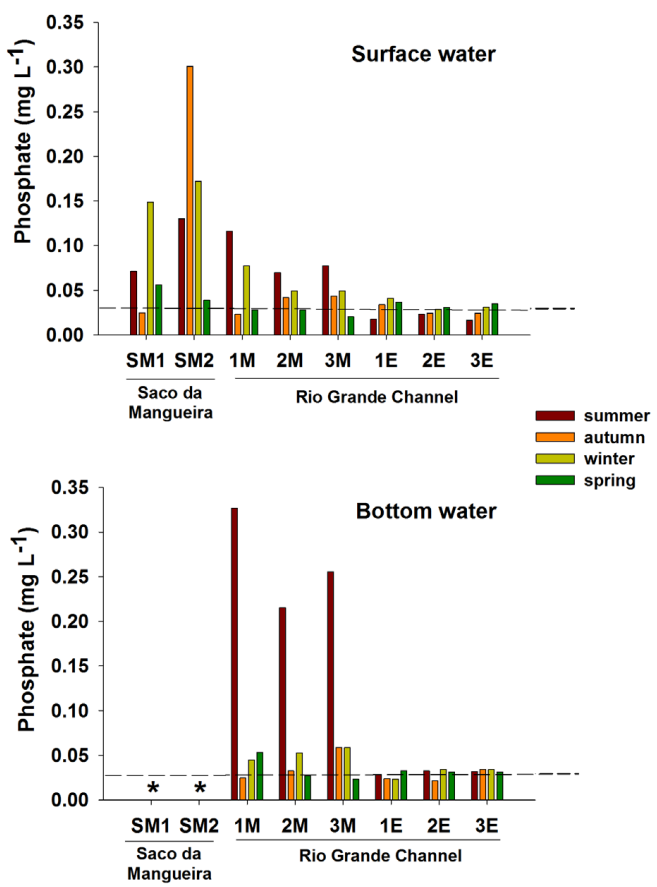

Figure 2. Seasonal variation of total phosphorus and phosphate (mg.L-1 $)$ at the margin of the Saco da Mangueira (sites SM1 and SM2) and in the Rio Grande Channel at the margin (sites 1M, 2M and 3M) and in the channel (sites $1 \mathrm{E}, 2 \mathrm{E}$ and $3 \mathrm{E}$ sites) in 2011. Dashed lines: reference values of $0.186 \mathrm{mg} \cdot \mathrm{L}^{-1}$ for total phosphorus (CONAMA, 2005) and $0.031 \mathrm{mg} . \mathrm{L}^{-1}$ for phosphate (Aminot \& Chaussepied, 1983). ${ }^{*}$ Data are absent because of the low depth in the local. 

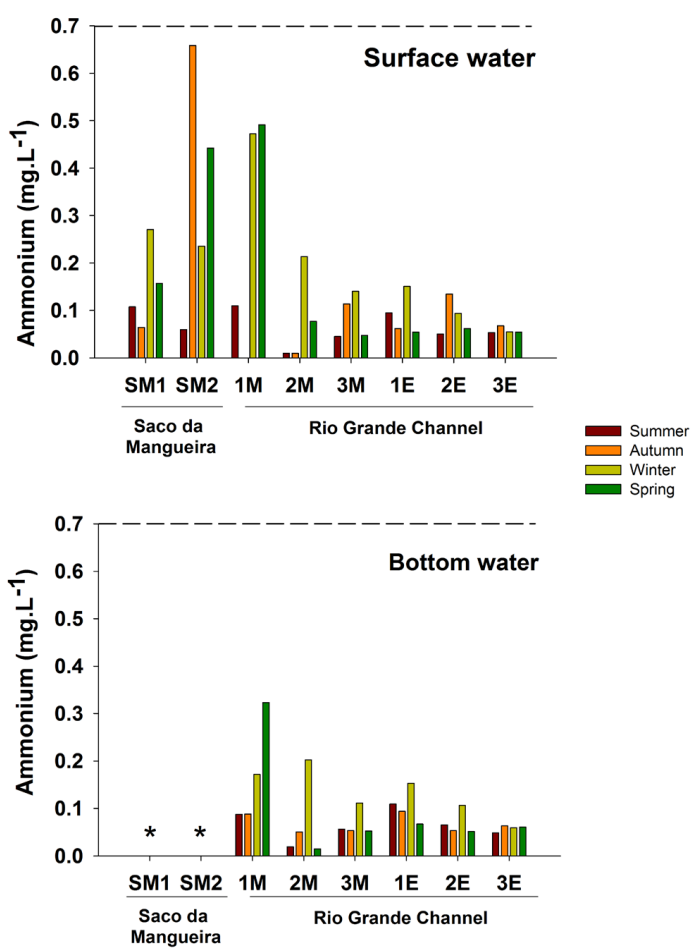

Figure 3. Seasonal variation of ammonium (mg.L $\left.\mathrm{L}^{-1}\right)$ at the margin of the Saco da Mangueira (sites SM1 and SM2) and in the Rio Grande Channel, at the margin (sites 1M, $2 \mathrm{M}$ and $3 \mathrm{M}$ ) and in the channel (sites $1 \mathrm{E}, 2 \mathrm{E}$ and $3 \mathrm{E}$ ) in 2011. Dashed line indicates the limit established by CONAMA (2005) (0.7 mg. $\left.\mathrm{L}^{-1}\right) .{ }^{*}$ Data are absent because of the low depth in the local.

\subsection{Trophic State Index (TSI)}

Total TSI values enabled to classify waters at the channel axis into eutrophic (the limit of the value) and ultraoligotrophic, ranging from 42 to 59 in the sites under investigation (Figure 4).

However, the TSI in the waters at the Saco da Mangueira ranged from 77.6 (SM2) to 60.6 (SM1) in fall, a fact that characterized trophy in these sites, thus, they were classified into hypertrophic and eutrophic. A milder but trophic imbalance was also observed at the margin of the channel, where the maximum TSI was 77.1 (1E, on the surface, in summer) and the minimum TSI was 54.1 (3E, on the bottom, in winter). Therefore, these waters were classified into hypertrophic and mesotrophic.

\section{Discussion}

\subsection{Ammonium}

Even though this nutrient is not included in the TSI calculations, it is important to evaluate water trophy because it is the product of microbiological decomposition of organic matter, which is the
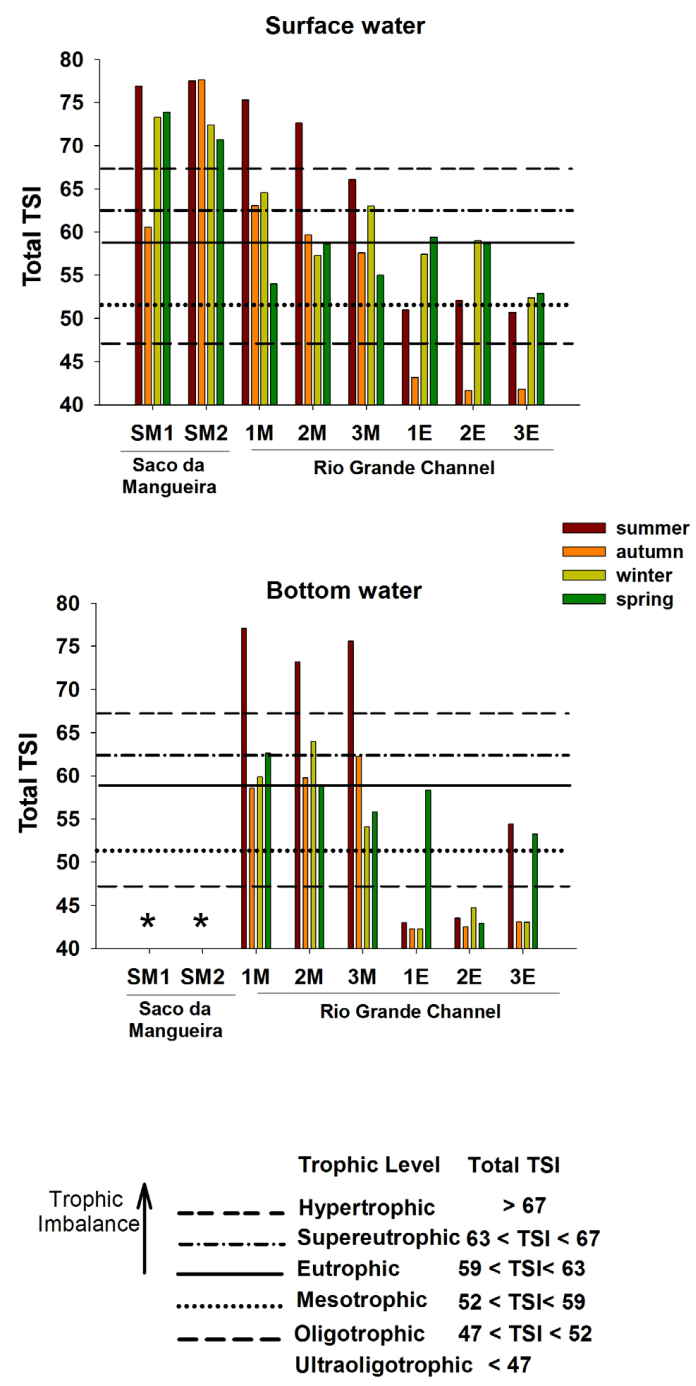

Figure 4. Seasonal variation of the total Trophic State Index (total TSI) at the margin of Saco da Mangueira (sites SM1 and SM2) and in the Rio Grande Channel, at the margin (sites $1 \mathrm{M}, 2 \mathrm{M}$ and $3 \mathrm{M}$ ) and in the channel (sites 1E, 2E and 3E) in 2011. ${ }^{*}$ Data are absent because of the low depth in the local.

preferable form of phytoplankton assimilation (Esteves, 1998). Large concentrations of ammonium in estuaries come from domestic effluents and decomposition of organic matter in the sediment re-suspended by currents and turbulence. The Patos Lagoon estuary receives much input of nitrogenous organic matter and ammonium, which is considered a great chemoindicator of this kind of contamination in this estuary (Baumgarten et al., 2001).

Data of this phytonutrient in channel and in bottom waters show that the concentrations were below the maximum limit recommended by CONAMA (2005), considering the relatively large tolerance of the reference value for brackish 
waters, Class $2\left(0.7 \mathrm{mg} \cdot \mathrm{L}^{-1}\right)$. It occurs because this legislation establishes limits based on toxicity to the biota; ammonium is eutrophic for the environment, but little toxic (Baumgarten \& Pozza, 2001).

The high values found in the surface waters at the margins of the Saco da Mangueira (SM1 and SM2) and at Porto Velho (1M) (Figure 3) are due to dispersion to the environment, of industrial and domestic effluents which are rich in biodegradable organic matter, a fact that can be confirmed by the negative correlation between ammonium and salinity $\left(r^{2}=-0.62\right)$, since the seawater favors the ammonium dilution and oxidation (nitrification). This process is favored in the ebb regime and in the presence of freshwaters. In site SM1, addition of ammonium may result from effluents released by a fish industry, which is located nearby. In site SM2, the origin may be the effluents of an adjacent vegetable grain processing company since they are rich in ammonium and have high $\mathrm{BOD}_{5}$. Baumgarten (2010) reported the contamination - based on the increase in concentrations of phytonutrients (ammonium and phosphate) and $\mathrm{BOD}_{5}$ - in the waters of a channel for pluvial outflow located beside that industrial plant.

Increase in ammonium at site $1 \mathrm{M}$ at Porto Velho, may be related to a fishing pier where fish is charged and discharged to be processed. It represents a potential source of organic matter to be decomposed in the marginal water. Increases in the results of $\mathrm{BOD}_{5}$ and suspended matter, parameters related to the occurrence of trophic disturbances in the environment; corroborate the hypothesis that the source of additional ammonium is the effluent rich in scavengable and biodegradable organic matter.

Flooding regime in the channel, the inflow of coastal waters into the estuary favors the dilution of effluents which may even be embanked where they are released, rather than being dispersed. This condition was observed in summer when northeast winds predominated. It may explain the fact that few differences were found between concentrations on the margin and in channel and that contamination is more punctual.

In this period, at the Saco da Mangueira, just site SM1 had values above the limits established by the literature in the case of non-polluted estuaries (Day Junior et al., 1987, established limit $\left.0.07 \mathrm{mg} \cdot \mathrm{L}^{-1}\right)$. Even so, they were much lower than the limits recommended by the current legislation (CONAMA, 2005).

\subsection{Trophic State Index and correlated variables}

The concentration of variables connected to primary production (nutrients, chlorophyll $a$ and total phosphorus) is affected by environmental factors, such as the hydrological regime and winds patterns, and by differences among places regarding the origin and intensity of the input. It reinforced the importance of classifying trophic quality of aquatic environments based on the calculation of total TSI which accounts for the effect of the nutrient input on these environments.

Resulting TSI values showed the occurrence of broad spatial-temporal variations in the trophic quality of different types of aquatic environments in the Patos Lagoon estuary (channel and margins of the channel and of the Saco da Mangueira) (Figure 4). The waters in channel fit into a trophic balance pattern, which was almost constant along time in the sampling sites, whereas the marginal waters in the channel and at the Saco da Mangueira had strong trophic imbalance (high TSI values), mainly in summer.

The Saco da Mangueira indicated constant occurrence of trophic imbalance in marginal waters. This inlet had already been reported by Persich et al. (1996) and Baumgarten \& Paixão (2013) as euthrophic. Concerning chlorophyll $a$, waters at the Saco da Mangueira were enriched, a fact that highlighted the difference between this inlet and the other areas under investigation in the channel and on its margins. It is reinforced by the insignificant concentrations of chlorophyll $a$ in the waters in channel and slightly higher ones on its surface. At channel margins, they were 10-fold the concentration found in the waters in the axis. However, concentrations at the Saco da Mangueira reached 68.7 $\mu \mathrm{g} . \mathrm{L}^{-1}$ (site SM1, in spring) whereas the maximum value in the channel, even at the margins, was $17 \mu \mathrm{g} \cdot \mathrm{L}^{-1}$. Concentrations of this pigment tend to rise probable because of the rainfall increased at the end of the winter $(33.6 \mathrm{~mm})$ and the spring $(71.2 \mathrm{~mm})$. This favored the input of nutrients at the margins during ebb time of both periods, causing high eutrophication in this environment.

Phosphate nutrients, as well as chlorophyll $a$, had high concentrations at Saco da Mangueira where high concentrations of phosphate had already been reported by a previous study (Baumgarten et al., 2001). They were three-fold the ones found in other hydric areas in Rio Grande and its surroundings. In this study, phosphate concentrations at the margins were ten-fold the average ones in the channel; the highest values were found in the 
industrial district (SM2). Point sources of phosphate nutrients comprise domestic and industrial effluents, whereas diffuse sources comprise atmospheric depositions coming from phosphate fertilizer plants in the industrial district (Casartelli et al., 2008). Soybean processing companies and fertilizer plants release clandestine effluents into the waters in the Saco da Mangueira. Effluents released by grain processing companies carry a high load of organic matter, which degrades along its way to the inlet and provides important input of phosphorus and nitrogen. This input generates blooms in the outflow area, thus, causing hypereutrophy at the margins of the inlet. Theoretically, fertilizers plants do not have hydric effluents but release phosphate and nitrogenous effluents, through the air or the pluvial flow, contaminated by industrial dust. The emissions reach the waters in the inlet, deposit, then, re-dissolve and migrate to the water column (Baumgarten et al., 2001), thus, bringing about trophic imbalance, mainly in periods when the level of the water column is lower, such as summer. High concentrations of phosphate coincide with the ammonium ones (previously reported in this area) and corroborate with this hypothesis, since fertilizers are composed of nitrogen, phosphorus and potassium.

High concentrations of phosphate were found in bottom waters in summer at the margins of the Rio Grande Channel. According to Baumgarten \& Niencheski (2010), the entrance of saline water into the estuary favors the release of phosphate found in the sediment column, contaminated by deposits of phosphate particles, to the water column via interstitial water, which disperses along the area. At the channel, values are in agreement with the reference ones recommended for non-polluted estuaries (Aminot \& Chaussepied, 1983, limit $0.031 \mathrm{mg} . \mathrm{L}^{-1}$ for phosphate).

Total phosphorus indicated high concentrations at the Saco da Mangueira as the result of pluvial and mixed industrial and domestic effluents released at the margins of the city (several are clandestine ones) (Almeida et al., 1993). In spring, most phosphate releases were not yet dissolved, but in the form of particles. This is the reason why maximum values of total phosphorus did not coincide with the phosphate ones, a dissolved form of phosphorus. At the channel, concentrations are in agreement with the environmental legislation or with normal reference values (CONAMA, 2005, Class 2, brackish waters, limit $\left.0.186 \mathrm{mg} \cdot \mathrm{L}^{-1}\right)$.
The great occurrence of trophic imbalance (highest TSI's) at the marginal water in summer, both at the Saco da Mangueira and at the channel margins, may be explained because, in this season, probable because of the increase in temperature (which triggers cellular metabolism) results in bloom growth. Besides, at the margins of the estuary, this process is favored by lower water circulation caused by a decrease in the water level due to the permanence and dominance of saline water, which enters the estuary in this period. In this case, opportunistic microalgae blooms accumulate near the margins and lead to trophic imbalance.

The main blooms found at the Saco da Mangueira are basically composed of cyanobacteria Aphanothece sp, whose colonies form mucilaginous flakes when they are very concentrated. Since the flakes agglomerate and accumulate of the edges of the inlet, once decomposed, create a poorly oxygenated sediment and decrease natural biodiversity (Baumgarten, 2010). In general, exportation of these blooms to the channel increases eutrophication in the estuary.

However, high values of TSI recorded in winter (freshwater and ebb regime) and in spring (retention of highly mixoaline water) are evidence of the trophic imbalance in this inlet, regardless of the hydrologic regime. Differences in the intensity of the contamination found between both sites located at the Saco da Mangueira (SM1 and SM2) result from distinct water circulation in these sites as previously observed by Fernandes et al. (2007). The site SM1 (margin of the city) is characterized by less intense contamination resulting from partial dilution of the effluents by the higher water circulation.

In order to check which parameters were responsible for the value of total TSI in the marginal waters, coefficients of linear correlation were established between total TSI and the TSI's of total phosphorus, phosphate, chlorophyll $a$ and the other nitrogenous nutrients. Results showed that trophic imbalance in these waters were basically triggered by the high biomass of primary producers/blooms $\left(r^{2}\right.$ total TSI/TSI $\left.(\mathrm{Chl} a)=+0.639\right)$, which were greatly enabled by high input of total phosphorus $\left(\mathrm{r}^{2} \mathrm{TSI} / \mathrm{TSI}(\mathrm{TP})=+0.631\right)$, phosphate $\left(r^{2}\right.$ TSI/TSI $\left.(R S P)=+0.584\right)$ and ammonium $\left(r^{2}\right.$ TSI/ammonium $\left.=+0.465\right)$.

Waters in the axis of the channel indicated a rare situation of eutrophy in winter and spring during ebb tide in the estuary, when marginal waters and their compounds are mixed and exported to the 
channel. The pigment chlorophyll $a$ indicates algal biomass and works as a variable connected to the level of the trophic state of a water body. It is suggested that in these occasions, concentrations of nutrients kept relatively homogeneous between the sites in the channel. Besides, the values of the correlation coefficients in relation to total TSI for these waters were only high for chlorophyll $a\left(\mathrm{r}^{2}\right.$ TSI/TSI $\left.(\mathrm{Chl} a)=+0.902\right)$, unlike what was previously reported in the case of marginal waters. There was no significant correlation with ammonium, since this form of nitrogen is either diluted or assimilated. It may also oxidize before it reaches high concentrations on its way to the channel.

Therefore, low residence time of these waters, high depth of the channels and high oxygenation are responsible for providing high self-depuration power regarding anthropogenic input to the waters at the channel. In terms of compounds that cause eutrophy, it indicates that the high load of organic matter released into the margins gets to the channel half or totally decomposed. As a result, the products of its decomposition are also diluted and dispersed. Therefore, the dilution of nutrients makes the values of TSI's decrease and become more homogeneous in different sites with deeper waters.

Trophic disturbances identified at the margins of the estuary are evidence of the fact that these waters have received poorly treated effluents whose amounts exceed their self-depuration capacity. Baumgarten \& Paixão (2013) classified waters at Saco da Mangueira inlet into hypereutrophic and eutrophic ones, based on data collected in channel in spring 2002 and in 2006; those results were similar to the ones found by this study. In order to change this scenario of environmental degradation in these areas which are extremely important in terms of ecological and economic interests, stronger and more effective actions must be carried out by state and city authorities. These actions must increase surveillance of the release of clandestine domestic and, specially, industrial effluents at the Saco da Mangueira so that treatment becomes mandatory before they are released into the estuary.

The TSI results of this study are relevant as reference for future investigations and as a predictive tool for the Patos Lagoon estuary management. This modified index can be also used in other coastal lagoon areas with high input of phosphate.

\section{Acknowledgements}

The authors thank the Universidade Federal do Rio Grande for the logistical support and the Coordenação de Aperfeiçoamento de Pessoal de Nivel Superior (CAPES) for the financial support to Rafaela Neves Marreto.

\section{References}

ALMEIDA, M.T.A., BAUMGARTEN, M.G.Z. and RODRIGUES, R.M. Identificação das possiveis fontes de contaminação das águas que margeiam a cidade de Rio Grande - RS. Rio Grande do Sul: FURG, 1993. Documentos Técnicos Oceanografia, 6.

ALVES, G., FLORES-MONTES, M., GASPAR, F., GOMES, J. and FEITOSA, F. Eutrophication and water quality in a tropical Brazilian estuary. Journal of Coastal Research, 2013, 65, 7-12. http://dx.doi. org/10.2112/SI65-002.1.

AMERICAN PUBLIQUE HEATH ASSOCIATION - APHA. Phosphorus. In A.E. Greenberg, L.S. Clesceri and A.D. Eaton, eds. Standard methods for the examination of water and wastewater. 18nd ed. Washington: APHA/WEF/AWWA, 1992, pp. 108-112.

AMINOT, A., CHAUSSEPIED, M. Manuel des analyses chimiques em milieu marin. Bretagne: Centre National pour l'explotation dês oceans, Brest Documentation, 1983. Éléments nutritifs minéraux dissous, pp. 93158.

BAUMGARTEN, M.G.Z. A eutrofização das águas de uma enseada do estuário da Lagoa dos Patos (RS) protegida pela legislação ambiental. FEPAM em Revista [online], 2010, 3(2), 34-42 [viewed 12 Dec. 2016]. Available from: http://www.fepam.rs.gov.br/ fepamemrevista/ downloads/ Revista_ V3N2\%20 -\%202010\%20-\%20LEVE.pdf

BAUMGARTEN, M.G.Z. and NIENCHESKI, L.F.H. A coluna sedimentar como reservatório e fonte de nutrientes em enseadas estuarinas. Tropical Oceanography, 2010, 38(1), 88-104. http://dx.doi. org/10.5914/tropocean.v38i1.5163.

BAUMGARTEN, M.G.Z. and PAIXÃO, B.E.G. Uso do Índice de Estado Trófico para avaliar as águas do estuário da Lagoa dos Patos (RS). Revista Atlântica, 2013, 35(1), 5-22. http://dx.doi.org/10.5088/ atl.2013.35.1.5.

BAUMGARTEN, M.G.Z. and POZZA, S.A.P. Qualidade de águas: descriçāo de parâmetros químicos referidos na legislação ambiental. Rio Grande do Sul: FURG, 2001.

BAUMGARTEN, M.G.Z., NIENCHESKI, L.F. and VEECK, L. Nutrientes na coluna d'água e na água intersticial de sedimentos de uma enseada rasa estuarina com aportes de origem antrópica (RS). Revista Atlântica, 2001, 23(1), 101-116. 
BAUMGARTEN, M.G.Z., NIENCHESKI, L.F.H., WALLNER-KERSANACH, M., RIBEIRO, A.R.L. and MACHADO, E.C. Manual de análise em oceanografia química. 2. ed. Rio Grande: FURG, 2010. Análise Instrumental, pp. 81-128.

BRICKER, S.B., FERREIRA, J.G. and SIMAS, T. An integrated methodology for assessment of estuarine trophic status. Ecological Modelling, 2003, 169(1), 36-60. http://dx.doi.org/10.1016/S03043800(03)00199-6.

CALLIARI, L.J., WINTERWERP, J.C., FERNANDES, E., CUCHIARA, D., VINZON, S.B., SPERLE, M. and HOLLAND, K.T. Fine grain sediment transport and deposition in the Patos Lagoon-Cassino beach sedimentar system. Continental Shelf Research, 2009, 29(3), 515-529. http://dx.doi.org/10.1016/j. csr.2008.09.019.

CARLSON, R. A trophic state index for lakes. Limnology and Oceanography, 1977, 22(2), 362-369. http:// dx.doi.org/10.4319/lo.1977.22.2.0361.

CASARTELLI, M.R., MIRLEAN, N., PERALBA, M.C., BARRIONUEVO, S., GÓMEZ-REY, M.X. and MADEIRA, M. An assessment of the chemical composition of precipitation and throughfall in rural-industrial gradiente in wet subtropics (southern Brazil). Environmental Monitoring and Assessment, 2008, 144(1-3), 105-116. PMid:17891507. http:// dx.doi.org/10.1007/s10661-007-9949-y.

COMPANHIA AMBIENTAL DO ESTADO DE SÃO PAULO - CETESB. Relatório de qualidade das águas interiores no estado de São Paulo: 2006 [online]. São Paulo: CETESB, 2007 [viewed 12 Dec. 2016]. Série Relatórios. Available from: http://aguasinteriores. cetesb.sp.gov.br/publicacoes-e-relatorios/

CONSELHO NACIONAL DO MEIO AMBIENTE CONAMA. Resoluçáo CONAMA no 357. Decreto no 99.274 de 17 de março de 2005. Revoga Resolução CONAMA no 20 de 1986. Diário Oficial da República Federativa do Brasil [online], Brasília, DF, 30 jul. 2005 [viewed 12 Dec. 2016]. Available from: http://www.mma.gov.br/port/conama/legiabre. cfm? codlegi $=459$

DAY JUNIOR, J.W., HALL, C.A.S., KEMP, W.M. and YÁNEZZ-ARANCIBIA, A. Estuarine ecology. New York: John Wiley \& Sons, 1987.

ESTEVES, F.A. Fundamentos de limnologia. Rio de Janeiro: Interciências, 1998.

FERNANDES, E.H.L., MONTEIRO, I.O. and MOLLER JUNIOR, O.O. On the dynamics of Mangueira Bay - Patos Lagoon (Brazil). Journal of Coastal Research, 2007, 47, 97-107. http://dx.doi. org/10.2112/1551-5036-47.sp1.97.

FUNDAÇÃO ESTADUAL DE PROTEÇÃO AMBIENTAL - FEPAM. Portaria SSMA no 7 , NT 003/95. Enquadramento dos recursos hídricos do sul do estuário Lagoa dos Patos. Diário Oficial da
Uniâo [da] República Federativa do Brasil [online], 24 mai. 1995 [viewed 12 Dec. 2016]. Available from: http://portalpnqa.ana.gov.br/Publicacao/ Portaria_SSMA_n_07_de_95.pdf

GARCIA, C.A.E. Hydrographic characteristics. In: U. SEELIGER, C. ODEBRECHT and J.P. CASTELLO, eds. Subtropical convergence environments: the coast and sea in the Southwestern Atlantic. Berlin: Springer, 1997, pp. 18-20.

GUPTA, M. A new trophic state index for lagoons. Journal of Ecosystems, 2014, 2014(2014), ID152473. http://dx.doi.org/10.1155/2014/152473.

HARTMANN, C. and SCHETTINI, C.A.F. Aspectos hidrológicos na desembocadura da Laguna dos Patos, RS. Revista Brasileira de Geociências [online], 1991, 21(4), 371-377 [viewed 12 Dec. 2016]. Available from: http://repositorio.furg.br/bitstream/handle/1/3217/ Aspectos\%20hidrol\%C3\%B3gicos\%20na $\% 20$ regi $\% \mathrm{C} 3 \% \mathrm{~A} 3 \mathrm{o} \% 20 \mathrm{da} \% 20$ desembocadura $\% 20$ da\%20Laguna\%20dos\%20Patos\%2C\%20Rs. pdf?sequence $=1$

KJERFVE, B. Comparative oceanography of coastal lagoons. In: D.A. WOLFE, ed. Estuarine variability. New York: Academic Press, 1986, pp. 63-81.

LAI, J., JIANG, F., KE, K., XU, M., LEI, F. and CHEN, B. Nutrients distribution and trophic status assessment in the northern Beibu Gulf, China. Chinese Journal of Oceanology and Limnology, 2014, 32(5), 1128-1144. http://dx.doi.org/10.1007/ s00343-014-3199-y.

LAMPARELLI, M.C. Grau de trofia em corpos d'água do estado de São Paulo: avaliação dos métodos de monitoramento [Dissertação de Mestrado]. São Paulo: Instituto de Biociências, USP, 2004.

MACKINEY, G. Absorption of light by chlorophyll solutions. The Journal of Biological Chemistry, 1941, 140, 315-322.

MERCANTE, C.T.J. and TUCCI-MOURA, A. A comparação entre os índices de Carlson modificado aplicado a dois ambientes aquáticos subtropicais, São Paulo, SP. Acta Limnologica Brasiliensia [online], 1999, 11(1), 1-14. [viewed 12 Dec. 2016]. Available from: http://www.ablimno.org.br/acta/pdf/acta_ limnologica_contents $1101 \mathrm{E} \_$files/Artigo $\% 20$ 1_11(1).pdf

MÖLLER, O.O., CASTAING, P., SALOMON, J.C. and LAZURE, P. The influence of local e non-local forcing effects on the subtidal circulation of Patos Lagoon. Estuaries, 2001, 24(2), 297-311. http:// dx.doi.org/10.2307/1352953.

NIENCHESKI, L.F., WINDOM, H. and SMITH, R. Distribution of particulate trace metal in Patos Lagoon Estuary (Brazil). Marine Pollution Bulletin, 1994, 28(2), 96-102. http://dx.doi. org/10.1016/0025-326X(94)90545-2. 
O'BOYLE, S., MCDERMOTT, G., NOKLEGAARD, T. and WILKES, R. A simple index of trophic status in estuaries and coastal bays based on measurements of $\mathrm{pH}$ and dissolved oxygen. Estuaries and Coasts, 2013, 36(1), 158-173. http://dx.doi.org/10.1007/ s12237-012-9553-4.

OSGOOD, R.A. Using differences among Carlson's trophic state index values in regional water quality assessment. Journal of the American Water Resources Association, 1982, 18(1), 67-74. http://dx.doi. org/10.1111/j.1752-1688.1982.tb04529.x.

PERSICH, G.R., ODEBRECHT, C., BERGESCH, B. and ABREU, P.C. Eutrofização e fitoplâncton: comparação entre duas enseadas rasas no estuário da Lagoa dos Patos. Revista Atlântica, 1996, 18, 27-41.

RABALAIS, N., DIAZ, R., LEVIN, L., TURNER, R., GILBERT, D. and ZHANG, J. Dynamics and distribution of natural and human-caused hypoxia. Biogeociences, 2010, 7(2), 585-619. http://dx.doi. org/10.5194/bg-7-585-2010.

RGPILOTS. Praticagem da Barra do Rio Grande, 2003 - 2017 [online]. Rio Grande, 2016 [viewed 12 Dec. 2016]. Available from: http://www.rgpilots.com.br/

SANTOS, S.J.C. Determinação do estado trófico a partir da aplicação dos indices O'Boyle e TRIX nos compartimentos da Baía da Guanabara, RJ. Brasil
[Dissertação de Mestrado em Geociências]. Niterói: Universidade Federal Fluminense, 2015.

TOLEDO JUNIOR, A.P., TALARICO, M., CHINEZ, S.J. and AGUDO, E.G. A aplicação de modelos simplificados para a avaliaçáo e processo de eutrofização em lagos e reservatórios tropicais. In Anais do XII Congresso Brasileiro de Engenharia Sanitária. Rio de Janeiro: ABES, 1983, pp. 1-34.

VOLLENWEIDER, RA, GIOVANARDI, F, MONTANARI, G, RINALDI, A. Characterization of throphic conditions of marine coastal waters with special reference to the NW Adriatic Sea: proposal of a trophic scale, turbidity and generalized water quality index. Environmetrics. 1998; 9(3):329-57. http://dx.doi.org/10.1002/ (SICI) 1099-095X(199805/06)9:3<329::AIDENV308>3.0.CO;2-9.

WALLNER-KERSANACH, M., MIRLEAN, N., BAUMGARTREN, M.G.Z., COSTA, L.D.F. and BAISCH, P. Temporal evolution of the contamination in the southern area of the Patos Lagoon estuary, RS, Brazil. Journal of Integrated Coastal Zone Management, 2016, 16(3), 263-279. http://dx.doi.org/10.5894/rgci596.

Received: 12 December 2016 Accepted: 03 July 2017 